\title{
NATIONAL SECURITY, THE RIGHT TO TRAVEL, AND THE COURT
}

One of the first casualties of the Cold War was freedom of travel. Although most Americans continued to receive passports routinely, others found themselves singled out for special restrictions. For example, Arthur Miller was denied permission to see the opening of one of his plays in Brussels. His trip was said to be not in the "best interest of the United States." ${ }^{1}$ Perhaps the most frequent targets of travel control were artists ${ }^{2}$ and scientists, ${ }^{3}$ but other groups, such as Unitarian ministers, also faced barriers to travel. ${ }^{4}$ Even dissident Congressmen, ${ }^{5}$ federal judges, ${ }^{6}$ and congressional investigators ${ }^{7}$ were not immune.

Daniel A. Farber is Associate Professor of Law, University of Minnesota.

AUTHOR'S NOTE: The author would like to thank Dianne Farber for her editorial assistance and Professor Yale Kamisar for his helpful suggestions.

'See Parker, The Right to Go Abroad: To Have and to Hold a Pasport, 40 VA. L. REv. 853, 858 (1954).

${ }^{2}$ See Jaffe, The Right to Travel: The Pasport Problem, 35 Foreign AfFaIRs 17, 24 (1956); Comment, Pasport Refusals for Political Reasons, 61 YALE L. J. 171, 176-78 (1952).

${ }^{3}$ Comment, note 2 supra, $174-76,178 \mathrm{n}$. 58. A notable example was the denial of a passport to Linus Pauling, the Nobel Laureate. Chafee, Book Review, 101 U. PA. L. REv. 703,705 (1953).

${ }^{4}$ See Jaffe, note 2 supra, at 24.

5 See Comment, note 2 supra, at 176. For further details, see text accompanying notes 83-90 infra.

${ }^{6}$ See Parker, note 1 supra, at 859 . In another instance, the government refused to allow travel by a lawyer involved in international litigation. See Boudin, The Constitutional Right to Travel, 56 CoL. L. Rev. 47, 66 (1956).

${ }^{7}$ Parker, note 1 supra, at 860 . The informant had been previously imprisoned and then deported by Switzerland for his activities.

(C) 1982 by The University of Chicago. All rights reserved.

$0-226-46434-2 / 82 / 1981-0026 \$ 01.00$ 
This period of travel control ended in 1958 when the Supreme Court decided Kent v. Dulles. 8 The court held in Kent that the President lacked statutory authority to restrict foreign travel by Communists and other political dissidents. Some twenty-three years later, however, the Court held in Haig v. Agee ${ }^{9}$ that the President could restrict travel by individuals whose conduct abroad might seriously injure the national interest.

The Agee Court surely did not intend to resurrect the discredited practices of the 1950s. Agee, a renegade CIA agent, presented a much different problem than the artist involved in Kent $v$. Dulles. In an earlier case, the Court had already shown its antipathy toward renegade agents by imposing harsh penalties on violators of CIA secrecy regulations. ${ }^{10}$ Moreover, the Agee Court went out of its way to distinguish Kent, which clearly remains a bar to purely ideological restrictions on travel. ${ }^{11}$

Although the holding in Agee was clearly incorrect, the route the Court took there is more disturbing than the holding itself. It might well have been reasonable for Congress to deny passports to individuals such as Agee. Nevertheless, the President quite clearly lacked the statutory power to do so. This conclusion is required not only by Kent but by intervening legislative developments. To reach its result, the Agee Court had to go to extraordinary lengths. First, while not overruling the specific holding of Kent, the Agee Court had to distort completely the Kent rationale; thus, Kent has apparently been abandoned sub silentio. Second, the Curt resorted to extraordinary distortions of the historical record. Even a cursory examination of the Court's sources reveals serious inaccuracies in the opinion. In particular, the Court omits any reference to crucial legislative history which was brought to its attention in the briefs. ${ }^{12}$ The historical materials that the Court does cite are misdescribed in significant ways. ${ }^{13}$

These flaws in the opinion go beyond mere defects of craftsmanship and suggest rather a breakdown of principled adjudication.

\footnotetext{
${ }^{8} 357$ U.S. 116 (1958).

${ }^{9} 101$ S. Ct. 2766 (1981).

${ }^{10}$ Snepp v. United States, 444 U.S. 507 (1980) (per curiam). Snepp is discussed in more detail infra at text accompanying notes 146-48.

${ }^{11}$ See Agee, 101 S. Ct. at 2780-81.

${ }^{12}$ See text accompanying notes 103-27 infra.

${ }^{13}$ See text accompanying notes 74-102 infra.
} 
The Court seems to have been willing to abandon all else in its eagerness to uphold the government's national security claim. In contrast, the possible effects of the decision on the civil liberties of other travelers do not seem to have interested the Court. For instance, the Court did little to delineate the limits of executive discretion in future passport cases. This attitude is the most disturbing aspect of the case. If it simply reflects the unappealing facts of the Agee case, it is regrettable but perhaps not alarming. If, on the other hand, it is an indication of the Court's future performance in resolving clashes between civil liberties and national security, then the prospect is indeed gloomy.

I.

Neither Kent nor Agee can be understood without some familiarity with the history of passport regulation. Two separate, but related, lines of statutes are involved. One line of statutes has authorized the Secretary of State to issue passports to citizens who request them. The other line of statutes, known as travel control acts, has required at various times that citizens have passports in order to leave the country, except when this requirement is waived by the President. These travel control acts presuppose that the executive has authority to issue passports, but they do not themselves grant this authority or authorize denial of passports to particular individuals.

The Secretary of State has been authorized by statute to issue passports since $1856 .{ }^{14}$ In the nineteenth century, passports were generally not required either by American law or by foreign countries. ${ }^{15}$ They functioned as identification documents or letters of introduction rather than as travel control documents. During this period, the executive claimed unbridled discretion over the issuance of passports. ${ }^{16}$ Passports began their metamorphosis into travel control documents ${ }^{17}$ with the passage of the 1918 Travel Control

\footnotetext{
${ }^{14}$ See Agee, 101 S. Ct. at 2775-76, for an account of American passport practices in the nineteenth century.

15 Jaffe, note 2 supra, at 17; Parker note-1 supra, at 863; Comment, note 2 supra, at 172 (stating that in 1897 only four countries required passports).

${ }^{16}$ See Association of the Bar of the City of New York, Freedom to Travel:

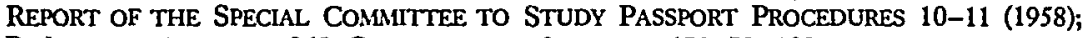
Parker, note 1 supra, at 865; Comment, note 2 supra, at 172-73, 189.
}

${ }^{17}$ See Jaffe, note 2 supra, at 17. 
Act, requiring a passport for entry into or departure from the country. ${ }^{18}$ In 1926, Congress passed the current Passport Act. The 1926 Act simply authorizes the Secretary of State to issue passports under such rules as the President may prescribe. No statutory standards are provided. ${ }^{19}$ The 1918 Travel Control Act was reactivated in 1941 for the duration of World War II. ${ }^{20}$ After the war, the requirement of a passport for foreign travel was extended into the subsequent period of national emergency. ${ }^{21}$ That "national emergency" did not expire until $1978 .^{22}$

Until 1952, administrative regulations under the Passport Act contained no standards for passport denial except in wartime. Executive orders in 1928, 1932, and 1938 gave the secretary discretion to refuse to issue a passport, but provided no standards. ${ }^{23}$ Observers agree that passports were often denied on political grounds in the postwar period. ${ }^{24}$ This is difficult to document, however, because the secretary's customary explanation was simply that denial of the passport was "in the national interest," with no further elaboration. ${ }^{25}$ In 1952, for the first time, the State Department adopted a regulation expressly stating a national security ground for denial. The 1952 regulation prohibited the issuance of passports to Communist Party members, individuals under the control of the Communist Party, and anyone else whose activities

1840 STAT. 559.

${ }^{19}$ See 22 U.S.C.A. $\$ 211$. The executive continued to claim total discretion over the issuance of passports until the 1950s. See Jaffe, note 2 supra, at 21.

2055 STAT. 252.

21 See Briehl v. Dulles, 248 F.2d 561, 570 (D.C. Cir. 1957) (en banc).

22 See National Emergencies Act, \$ 101, 90 STAT. 1255 (1976).

${ }^{23}$ See Executive Order No. 4800, $\S 1(1), 77$ (1928); Executive Order No. 5860, $\S ~ 1(1)$, 117 (1932); Executive Order No. 7856, 3 Fed. Reg. 805 (1938), codified at 22 C.F.R. $\$ \$ 51.75$, 51.77 (1949). The Agee Court mistakenly cites these executive orders as part of "an unbroken line of Executive Orders [and] regulations" in which "the President and the Department of State left no doubt that likelihood of damage to national security or foreign policy of the Umited States was the single most important criterion in passport decisions." Agee, $101 \mathrm{~S}$. Ct. at 2777. Actually, these executive orders focus on proof of citizenship and say nothing about national security or foreign policy. See Boudin, Tbe Constitutional Rigbt to Travel, 56 CoL. L. REv. 47, 55 (1956) ("[n]ot a single executive order . . . sought to impose substantive conditions" on passport issuance); Briehl v. Dulles, 248 F.2d 561, 580-81 (D.C. Cir. 1957) (Bazelon, J., dissenting). See also note 25 infra.

24 See Jaffe, note 2 supra, at 24; Comment, note 2 supra, at 174.

25 N.Y. BAR Ass'N, note 16 supra, at 11 ("[b]efore 1952 one could search in vain for any standards applied with sufficient consistency to be called a discernible policy"); Ehrlich, Pasports, 19 STAN. L. REV. 129, 131 (1966); Comment, note 2 supra, at 173-74. 
abroad would intentionally aid the Communist movement. ${ }^{26}$ This was the regulation at issue in Kent.

Kent involved two plaintiffs, both of whom had been denied passports under the regulation. One was the artist Rockwell Kent, who wished to paint pictures in Europe. He also wished to attend a meeting of a group called the "World Council of Peace" in Helsinki. The other plaintiff was Walter Briehl, a physician, who wished to attend psychiatric conferences in Geneva and Istanbul. ${ }^{27}$ In an en banc decision, the D.C. Circuit held that the 1952 regulation was authorized by the Passport Act. ${ }^{28}$ A lengthy dissent by Judge Bazelon argued that the regulation exceeded the State Department's authority. ${ }^{29}$

The government's position underwent a significant change in the Supreme Court. In its brief, the government argued that issuance of a passport was "wholly discretionary"30 and that this discretion was ratified by Congress in the Passport Act and various travel control statutes. ${ }^{31}$ To his credit, however, Solicitor General Rankin had qualms about his position. At oral argument, he was clearly troubled by the civil liberties aspect of the case. He continued to argue that the Passport Act had originally granted unlimited discretion. He contended, however, that this grant of authority was valid only so long as passports were unnecessary for travel. ${ }^{32}$ With the transformation of passports into travel control documents, the fundamental nature of the passport changed, and the permissible grounds for discretion narrowed. That is, insofar as passports were used to control travel, the source of power had to be found in the Travel Act rather than in the Passport Act. ${ }^{33}$ The Court plainly found this line of argument somewhat confusing.

The Court nevertheless held that the regulation was unau-

${ }^{26} 17$ FED. REG. 8013 (1952), codified at 22 C.F.R. $\$ 51.135$ (1958).

${ }^{27}$ See Kent v. Dulles, 248 F.2d 600 (D.C. Cir. 1957) (en banc); Briehl v. Dulles, 248 F.2d 561,563 (D.C. Cir. 1957) (en banc).

${ }^{28}$ Id. at $572-73,576$.

${ }^{29} \mathrm{Id}$. at 596.

${ }^{30}$ Brief for Respondent in Kent v. Dulles at 37.

31 Id. at 36-57.

${ }^{32} \mathrm{Tr}$. of Oral Arg. at 14-15 (reprinted with original pagination in 53 KuRLAND \& Casper, LANDMARK Briefs AND ARguments of THE Supreme Court of the UNITEd STATES 1089-1123 [1975]).

33 Tr. of Oral Arg. at 26-27. 
thorized by the Passport Act and therefore invalid. The opinion, written by Justice Douglas, stressed the importance of freedom of travel. Because this right is an important component of constitutional liberty, the Court construed the delegation of power to the secretary narrowly. ${ }^{34}$ It was willing to construe congressional approval to extend not to all the power historically claimed by the executive but only to the power actually exercised. Putting aside wartime measures which it found irrelevant, ${ }^{35}$ the Court concluded that only two classes of practices had sufficiently "jelled" to have received meaningful congressional acquiescence: (1) denial of passports to noncitizens, and (2) denial of passports to those engaged in illegal conduct. In contrast, the Court found only scattered and inconsistent rulings respecting Communists and held these insufficient to uphold the challenged regulation. ${ }^{36}$

Justice Clark, joined by three other Justices, dissented. Relying largely on the travel control statutes, he argued that Congress had specifically approved denial of passports in national security cases. $\mathrm{He}$ also pointed to instances in which passports had been denied during peacetime on national security grounds. ${ }^{37}$ His dissent foreshadowed the approach taken by the Court a quarter-century later in Agee.

A companion case to Kent involved rather vague accusations that a physicist was in some way associated with several espionage suspects. Based on these vague accusations, his passport application had been denied on the ground that he was "going abroad to engage in activities which will advance the Communist movement for the purpose, knowingly and willfully of advancing that movement."38 Finding this ground for denial indistinguishable from that involved in Kent, the Court reversed the lower court's judgment in favor of the secretary. ${ }^{39}$

${ }^{34}$ Kent, 357 U.S. at $125-27,129-30$.

${ }^{35}$ Id. at 128 . The Agee Court relied heavily on wartime practices. See Agee, 101 S. Ct. 2776-77, 2780.

${ }^{36} \mathrm{Kent}, 357$ U.S. at $127-28$.

${ }^{37}$ Id. at $131-43$.

${ }^{38}$ Dayton v. Dulles, 357 U.S. 144, 153 (1958). This basis for denial seems almost indistinguishable from the standard applied in Agee's case.

${ }^{39} \mathrm{Id}$. at 150 . Justices Clark, Burton, Harlan, and Whittaker dissented. They contended that "the Secretary of State is authorized to deny a passport to an applicant who is going abroad with the purpose of engaging in activities that would advance the Communist cause." Id. at 154 . The majority apparently disagreed. 
Two Supreme Court decisions from the mid-sixties should be mentioned as a prelude to the Agee case. In Aptbeker v. Secretary of State, ${ }^{40}$ the Court struck down a statutory ban on the issuance of passports to Communists. (This ban had not been in effect at the time of the Kent decision.) The statute was held to be too broad an intrusion on the constitutional right to travel because it indiscriminately presumed that all travel by Communists was dangerous to the national security. In the other case, Zemel v. Rusk, ${ }^{41}$ the Court upheld a ban on the use of passports for travel to Cuba. This ban was implemented through language on the passport prohibiting its use for travel to Cuba. The Court found a consistent history of such "area restrictions" on travel. The Court upheld the constitutionality of the area restrictions on the theory that they were supported by the "weightiest considerations of national security." 42 The same considerations of national security would also weigh heavily in the Agee case.

II.

The Agee litigation was an outgrowth of Philip Agee's campaign against the CIA. Agee, a former CIA agent, is an American citizen but currently resides in West Germany. In the course of his campaign, he has been responsible for producing several exposés about the agency. His actions are not only a breach of trust but also violate his secrecy agreement with the agency as well as an injunction enforcing that agreement. In 1979 , as a result of these activities, the United States revoked his passport. ${ }^{43}$ This action was

40378 U.S. 500 (1964).

11381 U.S. 1 (1965), noted in 13 U.C.L.A. L. REv. 470 (1966). Zemel foreshadows later cases rejecting claims of a First Amendment right of access to information. With the exception of access to criminal trials, such claims have been rejected so long as the ban on access is nondiscriminatory, as it was in Zemel. See Richmond Newspapers, Inc. v. Virginia, $100 \mathrm{~S}$. C. 2814 (1980); Houchins v. KQED, 438 U.S. 1 (1978); Pell v. Procunier, 417 U.S. 817 (1974). See generally LOCKHART, KAMISAR, \& CHOPER, CONSTITUTIONAL LAW 36 (1981 Supp.).

$1238 \mathrm{I}$ U.S. at 16. Between Zemel and Agee, freedom of travel was less extensively discussed in the legal literature. For discussion of the intervening developments, see Ehrlich, Paoports, 19 STAN. L. Rev. 129 (1966); Comment, The Rigbt to Travel and the Loyalty Oath, 12 COL J. TransnaT'L L. 387 (1973); Developments in the Law-National Security, 85 HARV. L. REV. 1141 (1972). Much of this discussion was directed toward the problems encountered by the State Department in attempting to enforce area restrictions.

${ }^{13}$ These background facts are drawn from the Agee opinion, $101 \mathrm{~S}$. Ct. at 2769-71. 
based on a 1966 regulation authorizing passport denial when a citizen's "activities abroad are causing or are likely to cause serious damage to the national security or the foreign policy of the United States." 44

Agee immediately filed suit challenging the validity of the 1966 regulation. Affidavits filed by the government explain in some detail the charges against him. The government was primarily concerned with Agee's repeated disclosures of the names of CIA agents, which jeopardized not only their work but also their safety. ${ }^{45}$ An affidavit by the Deputy Director for Operations conceded that American officials have been deliberately exposed as CIA agents in "numerous instances" not involving Agee. ${ }^{46}$ The affidavit also admitted that these exposures might have damaged the effectiveness of these agents. The affidavit maintained, however, that "there is . . . an enormous difference between an allegation of CIA connection by hostile foreign governments and foreign publications on one hand, and a similar allegation by a former CIA employee such as Mr. Agee on the other." 47 A later affidavit by the Deputy Director explained the reasons for restricting Agee's travel. Agee's ability to travel was allegedly essential to finding, recruiting, and training his collaborators. Also, his public announcements had greater impact, accordingto the Deputy Director, when Agee made them in the country involved in the disclosures. As an example of the harm Agee might do, the affidavit cited newspaper reports concerning possible cooperation between Agee and the captors of the American hostages in Iran. ${ }^{48}$ Although the record is unclear, these reports seem to have triggered the decision to revoke Agee's passport. ${ }^{49}$ For purposes of his motion for summary judgment, Agee conceded the government's factual allegations. ${ }^{50}$

4431 FED Reg. 13544, codified at 22 C.F.R. $\$ 51.70(\mathrm{~b})(4)$. An earlier version of the regulation, adopted in 1956, was broader. It covered all travel "prejudicial to the orderly conduct of foreign affairs or . . . otherwise prejudicial to the interests of the United States." 21 FED. REG. 336.

45 This is made clear, for example, in the government's petition for certiorari, pp. 4-5 and 11; see also Appendices D and E to the Petition.

46 Affidavit of John N. McMahon, Pet. for Certiorari, Appendix E, at 111 .

${ }^{47}$ Id. at $111 \mathrm{a}-112 \mathrm{a}$.

${ }^{48}$ Affidavit of John N. McMahon in Support of Motion for Stay Pending Appeal, Petition for Certiorari, Appendix F, at 114a-118a.

${ }^{49}$ See Agee v. Muskie, 629 F.2d 80, 81 \& n.I (D.C. Cir. 1980).

so See Joint Appendix at 11, 14-20. 
District Judge Gesell granted Agee's motion for summary judgment. In a brief opinion, he held that the 1966 regulation was unauthorized by Congress. He stressed that the regulation had only been used on one previous occasion. ${ }^{51}$ The government had relied heavily on broad statements of executive authority made in hearings in 1957. Judge Gesell countered by noting that, in 1958, Congress had denied a presidential request for "the precise authority sought here." "Implied authority is not," he observed, "gained in this fashion." $"$ 2

The government appealed to the D.C. Circuit, which affirmed Judge Gesell's order. ${ }^{53}$ The opinion was by Judge Robb. After a careful review of Kent and Zemel, Judge Robb concluded that in the absence of any express delegation of power, the government needed to show a "'sufficiently substantial and consistent' administrative practice to warrant finding the implied approval of Congress." 54 Like Judge Gesell, he found insufficient evidence of such a consistent administrative practice. Rather, he found only scattered instances in which the power was actually exercised. Except in the context of war or national emergency, which Kent held irrelevant to peacetime practices, the executive had rarely even asserted the existence of this power. ${ }^{55}$ Judge Mackinnon, the Court's most conservative member, wrote a lengthy and impassioned dissent accusing Agee of high treason. ${ }^{56}$

The government's petition for certiorari was granted on October $6,1980 .{ }^{57}$ In its brief and during oral argument, the government argued for a broad discretionary power over foreign travel. The brief particularly stressed the history leading up to the 1926 Passport Act as indicating congressional understanding of the secretary's broad powers in the area. ${ }^{58}$ The concern for civil liberties expressed in the Kent argument was absent from the government's argument in Agee. In the brief, freedom of travel was dismissed as

\footnotetext{
${ }^{51}$ Agee v. Vance, 483 F. Supp. 729, 731 (D.D.C. 1980).

52 Id. at 732 .

${ }^{53}$ Agee v. Muskee, 629 F.2d 80 (1980), noted in 22 HARv. INTERNAT'L L. J. 187 (1981).

54629 F.2d at 85 .

5s Id. at 86-87.

${ }^{56} \mathrm{Id}$. at 87-117. The treason discussion is at 112-17.

${ }^{57} 101 \mathrm{~S}$. Ct. 69. The Chief Justice previously had issued a stay.

${ }^{58}$ Brief for Petitioner at 22. See also id. at 35 (Congress was "aware of the Secretary's broad discretion" and ratified prior practice).
} 
not being a fundamental right. ${ }^{59}$ At oral argument, the government made it clear that it was asserting a broad grant of power: ${ }^{\mathbf{6 0}}$

QUESTION: General McCree, supposing a person right now were to apply for a passport to go to Salvador, and when asked the purpose of his journey, to say, to denounce the United States policy in Salvador in supporting the junta. And the Secretary of State says, I just will not issue a passport for that purpose. Do you think that he can consistently do that in the light of our previous cases?

SOLICITOR GENERAL MCCREE: I would say, yes, he can. Because we have to vest these-The President of the United States and the Secretary of State working under him are charged with conducting the foreign policy of the Nation, and the freedom of speech that we enjoy domestically may be different from that that we can exercise in this context.

This far-reaching claim clearly has implications extending well beyond Agee and other violators of national security laws. Apparently, the government sought the power to halt all extraterritorial dissent.

Chief Justice Burger wrote the opinion of the Court upholding the 1966 travel regulation. He opened with a lengthy canvass of the charges against Agee and the proceedings in the lower court. ${ }^{61}$ Turning to the statutory issue, he began by stressing the broad language of the Passport Act and the need for deference to "the consistent administrative construction of that statute." 62 As Justice Brennan pointed out in dissent, this was a glaring deviation from the test used in Kent. ${ }^{63}$ The Chief Justice then spent a considerable time reviewing the pre-1926 history of passport controls, concluding that Congress had ratified the "longstanding administrative con-

\footnotetext{
${ }^{59} \mathrm{Id}$. at 53.
}

${ }^{60}$ This exchange is quoted in Justice Brennan's dissent, $101 \mathrm{~S}$. Ct. at 2788 n.9. In 1958, the government specifically disclaimed any power "to deny passports to persons whose sole activity abroad would be to voice their own opinions." Hearings on the Right to Travel, Subcomm. on Const. Rights, Sen. Comm. on the Judiciary, 85 th Cong., 2nd Sess., pt. 2, 380 (1957).

${ }^{61}$ Agee, $101 \mathrm{~S}$. Ct. at 2769-73. Agee has complained that the Court's version of the facts was inaccurate. See Agree, I Don't Need a Passport, THE NEw YORK TIMES, July 27, 1981, at 15 , col. 1 .

${ }^{62}$ Agee, 101 S. Ct. at 2774.

${ }^{63}$ Id. at $2785-86$. 
struction" in 1926. ${ }^{64}$ Again, as Justice Brennan pointed out, this was an argument considered and rejected in Kent. ${ }^{65}$

Concerning the post-1926 history, the Chief Justice made three arguments in support of the regulation. First, he argued that Congress had been put on notice concerning the 1966 regulation and a similar 1956 regulation. He pointed to 1957,1960 , and 1966 congressional documents in support of this assertion. ${ }^{66}$ Second, he relied on a 1978 statute amending the Travel Act and the Passport Act as "weighty evidence of congressional approval." ${ }^{67}$ Third, he pointed to three instances in which passports were revoked on national security grounds. Despite the low number of incidents, he argued that the power had been consistently exercised because few situations involving serious threats to national security had arisen. ${ }^{68}$ These three arguments are at the heart of the Court's opinion.

The Court also rejected Agee's constitutional arguments. It held that national security was a sufficiently compelling interest to justify travel restrictions; that due process did not require a prerevocation hearing; and that Agee was not protected by the First Amendment. ${ }^{69}$ Since Agee's disclosures had "the declared purpose of obstructing intelligence operations," the disclosures were "clearly not protected by the Constitution." 70 In any event, the Court said, revocation of Agee's passport merely inhibited his conduct, not his speech. The Court left open the question whether Americans abroad enjoy any First Amendment protection. ${ }^{71}$ Given the impact of Agee's writing on the safety of government agents, the Court's First Amendment holding is not surprising. The Court's rationale, however, was hardly limited to the facts of the case.

64 Id. at 2777.

65 Id. at 2785-86. The pervasive inaccuracy of the Court's account of post-1926 history necessarily casts doubt on the accuracy of its account of earlier events. In addition, the Agee Court's argument really proves too much, for what the executive claimed prior to 1926 was unlimited discretion. See notes 19,23 , and 25 , supra. Yet no one, including the government, takes that position today. The government's brief, as noted in the text, claims "broad" but not infinite discretion.
66 Id. at 2778 .
67 Id. at 2779.
${ }^{68} I d$, at 2779-80.
${ }^{60} \mathrm{Id}$. at $2781-83$.
$70 \mathrm{Id}$. at 2783.
${ }^{71}$ Id. at 2782-83. 
Two Justices filed separate opinions. Justice Blackmun's brief concurrence argued that the Court had indeed, and in his view properly, disavowed aspects of Kent and Zemel. ${ }^{72}$ Justice Brennan, in dissent, argued that Agee was clearly governed by those cases. $\mathrm{He}$ called Agee "a prime exanıple of the adage that "bad facts make bad law." "73

The Court's opinion rests heavily on its analysis of the post-1926 history of travel control. That analysis contains serious distortions and omissions.

\section{ACTUAL ADMINISTRATIVE PRACTICE}

As evidence of a consistent adninistrative practice, the Court points to three episodes from 1948 to 1978. In each case, the Court's account of the episode is distorted.

The nuost recent of these episodes was in 1970. The Court says only that this episode involved "two persons who sought to travel to the site of an international airplane hijacking." " 74 These two persons turn out to have been the lawyers of Sirhan Sirhan, the convicted assassin of Senator Robert Kennedy. Early reports of the hijacking had indicated that the hijackers intended to negotiate for Sirhan's release. These reports were later repudiated. ${ }^{75}$ The government nevertheless refused to allow the lawyers to travel to the scene for the announced purpose of seeking the release of the hostages. ${ }^{76}$ Oddly enough, the government did not attempt to prevent Mrs. Sirhan fron proceeding with the journey. ${ }^{77}$ This somewhat undercuts the Court's claim that "in the cases which have arisen, the Secretary has consistently exercised his power to withhold

\footnotetext{
${ }^{72}$ Id. at 2783-84. Justice Blackmun's concurrence is more candid than the opinion of the Court. For reasons set forth iu detail later, however, his rejection of Kent and Zemel is misguided. See text accompanying notes $129-43$ infra.

${ }^{73} \mathrm{Id}$. at 2788 . His dissent was joined by Justice Marshall.

${ }^{74}$ Agee, $101 \mathrm{~S}$. Ct. at 2779 . Thus described, the incident hardly seems to fall under the 1966 regulation. After all, huudreds of media employees must have converged on the same spot.

75 New YORK Times, September 8, 1970, at 16, cols. 2, 6.

76 NEW YORK TIMES, September 9, 1970, at 16, col. 3. The lawyers said that they and Mrs. Sirhan would have been in the "best position to save the lives of the passengers." The incident was the subject of unreported litigation, which termiuated in the dismissal of an appeal on September 11. See Agee, 101 S. Ct. at 2780 n. 54.
}

${ }^{77}$ NEW YORK TIMES, September 9, 1970, at 16, col. 3. 
passports." 78 Moreover, the entire episode was obscure, never getting beyond page 16 of the New York Times. No evidence exists that anyone in Congress ever heard of this incident, which makes for weak evidence of implicit congressional approval.

The earlier episodes are described rather less accurately by the Court. One episode involved, according to the Court, "the 1954 revocation of a passport held by a man who was supplying arms to groups abroad whose interests were contrary to positions taken by the United States." 79 This is a somewhat peculiar way to describe an entirely legal sale of arms to the government of Guatemala. The man involved was Hubert Julian, also known as the Black Eagle of Harlem for his exploits as a World War II aviator. ${ }^{80}$ After arms shipments from Italy to Guatemala were seized, he spoke to the United States embassy in Paris. He informed the embassy that he was currently seeking arms only for friendly governments. According to Julian, the First Secretary of the embassy "scolded him for criticizing the United States Government."81 Julian's passport was seized when he left Paris for London. Two weeks later, it was returned. ${ }^{82}$ As in the Sirhan episode, the government's actions were not entirely consistent, nor was the episode likely to come to the attention of Congress.

The earliest episode is the most important. The Court's description of the episode merits quotation: ${ }^{83}$

Perhaps the most notable example of enforcement of the administrative policy, which surely could not have escaped the attention of Congress, was the 1948 denial of a passport to a Member of Congress who sought to go abroad to support a movement in Greece to overthrow the existing government.

The facts bear little relation to this description. Congressman Isacson, an American Labor Party representative, was an outspoken critic of American support for the Greek government. In a speech on March 13, 1948, he accused the Greek Army of "brutality and

\footnotetext{
${ }^{78}$ Agee, 101 S. Ct. at 2779.

${ }^{73}$ Ibid.

${ }^{80}$ New York Times, June 18, 1954, at 7, col. 3.

${ }^{81}$ Ibid.

${ }^{82}$ NFW YORK Timfs, July 12, 1954, at 2, col. 4. The July 12 story also fills in some of the details of the revocation.

${ }^{83}$ Agee, 101 S. Ct. at 2779.
} 
bestiality," including mass executions. ${ }^{84} \mathrm{He}$ also alleged (with some truth, as it turns out) that the administration was contemplating the use of American troops in Greece. ${ }^{85}$ In April, he announced plans for a fact-finding mission abroad, which was to include visits to Paris and Palestine. In Paris, he planned to observe the meetings of a group called the American Council for Aid to Democratic Greece. He was not a delegate to the meeting, but he was hoping to get more information about human rights violations. The State Department denied him a passport. Its explanation was that issuance of the passport was "not in the interests of the Government" because the "attitude" of the American Council toward U.S. policy was "well known." 86 While denying Isacson his passport, the government made no effort to prevent the departure of two men who were actually delegates to the conference. ${ }^{87}$ Once again, the administrative policy was inconsistently applied.

The episode did not involve any specific acts of unlawful, disloyal or otherwise improper conduct. The only apparent "threat" to U.S. interests was that Isacson would discover more human rights violations, which were proving an embarrassment to the government. ${ }^{88}$ The standard purportedly applied by the government

8494 CONG. REC. A2029, A2030 (1948) (remarks of Rep. Isacson). Isacson also attributed the passport denial to his criticism of Truman's policy toward Palestine. NEW YORK TIMES, April 4, 1948, at 30, col. 1.

8594 CONG. REC. A2031 (1948). Although Isacson's charges were exaggerated, government documents show that the option of using American troops was under active consideration. See 4 STATE DePT., Foreign Relations 5, 22-23, 25, 39, 93, 95, 99 (1948) (reprinting various State Dept., Defense Dept., and National Security Council documents). For further background on the United States role in Greece in this period, see GADDIS, THE UNITED STATES AND THE ORIGINS OF THE COLD WAR, 1941-1947, 346-52 (1972); FREELAND, THE TRUMAN DOCIRINE AND THE ORIGINS OF MCCARTHYISM 88-102 (1970). Freeland links the Greek crisis and the resulting Truman doctrine with the rise of McCarthyism. See id. at 140-50, 196-200, 241-45.

${ }^{86}$ NEw YORK TIMES, April 3, 1948, at 1, col. 6. (The only source cited by the Court is the TIMES, but unfortunately, the Court seems to have read only the skeletal account in the "Week in Review" feature. See Agee, 101 S. Ct. at 2779 n. 52, citing N.Y. TIMES, April 11, 1948, \& $\mathrm{E}$, at 9.)

THE TIMES editorialized that regardless of the innocence of Isacson's intentions, his mere presence at the conference would have undermined U.S. policy. It added that "[n]o citizen is entitled to go abroad to oppose the policics and interests of his country." NEW YORK TIMES, April 1948, \& E, at 8, col. 2 .

${ }_{87}$ NEW YORK TIMES, April 9, 1948, at 6, col. 6. The two individuals were the national vice-president of the American Council for Aid to Democratic Greece and another member of the group who was a New York City councilman.

${ }^{88}$ Isacson's atrocity cbarges had struck a nerve. The State Department had been secretly cautioning the Greek government that future executions could have an adverse affect on world opinion. See Telegram of the Secretary of State to the U.S. Embassy in Greece, 
(travel "not in the interests of the Government") was the same as that invoked when numerous other dissidents were denied passports. ${ }^{89}$ Seen in historical context, the Isacson episode was merely an early example of the abuses of the McCarthy period. ${ }^{90}$

The Agee Court was able to point to only these three episodes as examples of the challenged practice over a thirty-year period. Its excuse for the scarcity of examples was that the occasions for exercise of this power were equally rare. ${ }^{91}$ To support this claim, the Court had to make these episodes sound dramatic and highly extraordinary. In fact, scores of other travelers must have presented equal threats to American interests during the same period. For example, the Agee regulation never seems to have been invoked during the Vietnam War, despite notorious cases of travel to Hanoi in support of the Viet Cong. ${ }^{92}$ Although its administration was somewhat inconsistent, the regulation struck down in Kent was at least applied with some frequency. Other national security restrictions on passports have been applied with extreme rarity in cases apparently chosen at random. ${ }^{93}$ One major flaw in the Agee opinion

March 9, 1948, reprinted in 4 STATE DePT., Foreign Relations 60 (1948). (The Secretary's recommendation, ironically, was not that the Greeks halt the mass executions but that they come up with a better explanation.) See also id. at 74 (letter from the Acting Secretary of State responding to inquiry about executions).

${ }^{89}$ See text accompanying note 25 supra.

${ }^{90}$ Significantly, when Congress considered legislation to override Kent, both supporters and opponents of the legislation were anxious to see that it could not be used to limit the travel of Congressmen. See 105 CONG. REC. 18446 (1959) (remarks of Rep. Selden); id. at 18612 (remarks of Rep. Porter); id. at 18616 (remarks of Rep. Hays). This is a strong indication that Congress believed, at least after Kent, that the President lacked such power without additional legislation. For further discussion of this proposed legislation, see text accompanying notes $103-14$ infra.

${ }^{01}$ See Agee, $101 \mathrm{~S}$. Ct. at 2779-80. Additional incidents may have simply disappeared into the government's files, since the files are maintained by name and not otherwise indexed. See id. at 2787 n. 8 (Brennan, J., dissenting). Of course, as Justice Brennan points out, Congress could not very well have been aware of these episodes if even the State Department is unable to identify them.

${ }^{92}$ The Vietnam War episodes were extensively discussed in Congress, with Ramsey Clark and Jane Fonda being named as the most notorious offenders. See 118 CONG. REC. 33186 , 33188 (1972) (remarks of Rep. Ichord); id. at 33189 (remarks of Rep. Zion); id. at 3319333194 (remarks of Rep. Sikes); id. at 33195 (remarks of Rep. Montgomery). In 1980, Ramsey Clark and others went to Iran for a conference on Iranian grievances against the United States. They also met with the captors of the American hostages. This conduct was at least as much an affront to our foreign policy as Isacson's 1948 trip to Paris. Yet the passport laws were never invoked. See New YORK TIMES, June 8, 1980, at 8, col. 1.

${ }^{93}$ Like capital punishment, passport denial seems to have the same random quality as being struck by lightning, see Furman v. Georgia, 408 U.S. 238, 309 (1972) (Stewart, J., concurring). 
is its attempt to convert these few scattered instances into a consistent program.

\section{CONGRESSIONAL APPROVAL OF THE ADMINISTRATIVE PRACTICE}

To show congressional awareness of the challenged practice, the Court relies on "specific presentations" to Congress. These presentations consisted of "1957 and 1966 reports by the Department of State explaining the 1956 regulation" and a 1960 Senate Staff report. ${ }^{94}$ On inspection, none of these provides much support to the Court's position. The 1960 staff report was made to a committee with no jurisdiction over standards for passport issuance. ${ }^{95}$ Two years earlier, another report to a committee which did have jurisdiction had given contrary information. The earlier report concluded that, except in wartime, passport restrictions must be specifically authorized by Congress. ${ }^{96}$

The 1957 "presentation" cited by the Court turns out to be an offhand reference in testimony explaining various passport procedures. ${ }^{97} \mathrm{~A}$ memorandum submitted in the same hearing shows that passports were denied to non-Communists for a variety of reasons: mental incompetence, illegal activity, draft evasion, etc. One of these categories is labeled: "Persons Whose Activities Might $\mathrm{Be}$ Detrimental to Foreign Policy of the United States." 98 This turns out, however, to refer to actions that became grounds for expatriation in 1952, e.g., serving in foreign armies. As a result, after 1952 there was "seldom occasion to invoke the discretionary authority." 99 The memorandum also mentions that passports are sometimes denied at the request of other agencies when "individuals are engaged on highly classified projects." 100 The memo does not indi-

\footnotetext{
${ }^{94}$ Agee, 101 S. Ct. at 2778.

${ }^{95}$ Staff Report, Reorganization of the Passport Functions of the Department of State, Senate Comm. on Gov't Operations, 86th Cong., 2d Sess. (1960).

${ }^{96}$ Legislative Ref. Serv. of the Library of Congress, Passports and the Right to Travel: A Study of Administrative Control of the Citizen, 85th Cong., 2d Sess. 36 (1958) (printed for the use of the House Foreign Affairs Committee, also reprinted in the 1957 hearings, note 60 supra, at 158).

${ }^{97}$ Hearings, note 60 supra, at 59-61.

98 Ibid.

${ }^{99}$ Nicholas, Discretionary Refusal of Pasports in Non-Communist Cases (1955), reprinted in Hearings on the Right to Travel, note 97 supra, at 266.

100 Id. at 266-67.
} 
cate any general policy of screening passports for national security or foreign policy risks.

The 1966 "presentation" cited by the Court is also an offhand reference, no more than half a page out of thirty-eight pages of testimony by Philip Heymann. ${ }^{101}$ Moreover, the committee that heard the testimony had jurisdiction over Travel Act amendments but no jurisdiction over passport practices. ${ }^{102}$

Thus, the documents cited by the Court fail to lend much support to the inference of congressional approval. Congressional failure to respond to these far from forceful "presentations" seems more indicative of inattention than approval. At best, the documents weakly support the Court's position.

A much more important episode was cited to the Court but completely ignored in the opinion. In this episode, which followed the Kent decision, Congress was informed that the government lacked the power it later claimed in Agee. Despite urgent pleas from the administration, Congress refused to supply additional legislation. Because this episode is so critical, a detailed discussion is warranted.

Immediately following the Kent decision, President Eisenhower sent an urgent message to Congress calling for legislative action: ${ }^{103}$

In recent years the Secretary of State has based his limitation of passports on two general grounds. The first of these has been that an applicant's travel, usually to a specific country or countries, was inimical to United States foreign relations. The second of the general grounds of denial has been that an applicant is a member of the Communist Party; is under Communist Party discipline, domination, or control; or that the applicant is traveling abroad to assist knowingly the international Communist movement.

Recently the Supreme Court limited this power to deny passports under existing law. It is essential that the Government today have power to deny passports where their possession

${ }^{101}$ Proposed Travel Controls, Hearings on S. 3243 before the Internal Security Subcommittee of the Senate Judiciary Committee, 89th Cong., 2d Sess. 72 (1966). Although the Court fails to cite them, there are also brief relevant discussions at PP. 37 and 70 of the hearings. Two other aspects of Heymann's testimony are of interest. First, he indicated concern about allowing excessive discretion to the executive branch. Id. at 40 , Second, he indicated that any attempt to prevent an American citizen from returning to this country would be plainly unconstitutional. Id. at 56 .

${ }^{102}$ See id. at 51.

103104 CONG. REC. 13046, 33062 (1958). 
would seriously impair the conduct of foreign relations of the United States or would be inimical to the security of the United States.... .

I wish to emphasize the urgency of the legislation I have recommended. Each day and week that passes without it exposes us to great danger. I hope the Congress will move promptly toward its enactment.

Legislation was immediately introduced. Supporters pressed for fast action. ${ }^{104}$ As Senator Eastland, Chairman of the Internal Security Committee explained, the Chief Legal Officer of the Passport Division had given dramatic testimony in favor of the administration bill. According to Eastland: ${ }^{105}$

Mr. Johnson said that even if the Department knew that an American Communist planned to go to Moscow and take with him important American defense secrets for delivery to Communist espionage officials, the Department would not be able to deny him a passport to make the trip.

The House committee rejected the administration bill as giving too much discretion to the executive. Instead, it reported a bill creating a rebuttable presumption that Communist Party members would engage in harmful activities abroad. ${ }^{106}$ Supporters of the bill stressed that without it, the Secretary of State could not deny passports to persons traveling abroad in furtherance of Communist activities. ${ }^{107}$ The bill passed the House but failed to reach the Senate floor. ${ }^{108}$

In the next session of Congress, the President continued to press for action, citing "the total lack of legislative authority to deny passports to really dangerous participants in the international

104 Besides Senator Eastland's statement, note 105 infra, and the President's statement, there were other statements of the urgent need for legislation. See 104 CONG. REC. 19656 (1958) (remarks of Rep. Morgan); id. at 19655 (remarks of Rep. Selden); id. at 19656 (remarks of Rep. Gubser); 106 CoNG. REC. 16413 (1960) (remarks of Sen. Hruska). See also H. R. Rep. No. 1151, 86th Cong., 1st Sess. 2 (1959).

105104 CONG. REC. 13335 (1958). See Hearings, note 60 supra, at 379 (statement of the Under Secretary of State).

106 See 104 CoNG. REc. at 19655-19656 (remarks of Rep. Morgan).

${ }^{107}$ See id. at 19655 (remarks of Rep. Morano); id. at 19656 (remarks of Rep. Gubser).

${ }^{108}$ See 106 CONG. REC. 16076 (1960) (remarks of Sen. Lausche) (complaining of inaction by the Senate Committee on Foreign Relations). See also H. R. Rep. No. 1151, 86th Cong., ist Sess. 2 (1959). 
Communist conspiracy." 109 The House committee responded with a bill allowing denial of passports based on two concurrent findings: (1) Communist affiliation, and (2) likelihood of harm to U.S. security through foreign travel. ${ }^{110}$ The 1966 regulation upheld by the Court in Agee actually goes further, by making the second finding alone sufficient. Similar legislation was approved by the Senate committee, but the Senate bill applied only during war or national emergency. ${ }^{111}$ The reason for this restriction (also absent from the Agee regulation) was opposition by the State Department to broader controls. The State Department believed "it would be contrary to the traditional American dedication to the ideal of free travel to institute such controls in the absence of war or of any other national emergency. . . ."112 Even subject to these limitations, the legislation failed to pass. ${ }^{113}$

The legislative history is not conclusive on the Agee issue. All of the proposed legislation contained findings about the dangers posed by the international Communist movement. These findings were to be used in determining the likelihood that an applicant's activities abroad would injure national security. Thus, the legislation rejected by Congress was not quite identical to the Agee regulation. On the other hand, few members of Congress in 1958 or 1960 would have questioned these general findings about the dangers of Communism. Consequently, this aspect of the legislation is unlikely to have been the cause of rejection. In any event, the President's original message to Congress, as well as the testimony recounted by Senator Eastland, certainly gave Congress good reason

${ }^{109}$ Quoted in H. R. Rep. No. 1151 , note 108 supra, at 2.

110 See id. at 3.

11 S. Rep. No. 1811, Part 1, 86th Cong., 2d Sess. 16 (1960).

112 Letter from the Assistant Secretary of State to Sen. Eastland, May 6, 1959, reprinted id. at 8.

${ }_{113}$ The bill once again passed the House. The debates in the House stress that without the bill, passports could not be denied even to persons "[who] frankly state that they are going abroad to further the cause of international communism." 105 CoNG. REC. 18443 (1959) (remarks of Rep. Selden). See also id. at 18443-18444 (quoting a State Department memorandum to the same effect); id. at 18612 (remarks of Rep. Walters) (State Department completely lacks "any control on a security basis of the issuance of passports"); id. at 18613 (remarks of Rep. Fascell) (government needs authority to deny passports to those Communists "whose travel ahroad is found to be detrimental to U.S. security").

The bill never came up for a vote in the Senate. Apparently, it was killed by the Senate leadership. See 106 CoNG. ReC. 16416 (1960) (remarks of Sen. Cotton); id. at 16493 (remarks of Sen. Lausche); id. at 16940 (remarks of Sen. Curtis 16940); id. (remarks of Sen. Williams) (all complaining ahout their inability to get the bill on the calender for a vote). 
to think that the executive lacked the power it was later to claim in Agee. As Judge Gesell said in his district court opinion, "implied authority is not gained in this fashion." 114

\section{THE 1978 LEGISLATION}

Perhaps in recognition of the weakness of its other arguments, the Agee Court placed its primary reliance on 1978 legislation. It found this legislation to be "weighty evidence of congressional approval of the Secretary's interpretation, particularly that in the 1966 regulations." 115 The Court refrained from explaining the relevant legislative history, which in fact showed strong hostility to the whole idea of executive travel control. The 1978 legislation contained two relevant provisions. One amended the Passport Act, and the other affected the Travel Act.

The Passport Act amendment concerned area restrictions. Under the regulations in effect in 1978, such restrictions on the use of passports to travel to certain countries were limited. Area restrictions were allowed only when "such travel would seriously impair the conduct of United States foreign affairs." 116 This is a standard almost identical to that in the Agee regulation, but, in 1978, Congress rejected this standard. Although broad area restrictions were upheld in Zemel on the basis of the "weightiest considerations of national security," 117 the 1978 legislation allows their use only to protect travelers from physical danger. ${ }^{118}$ The Senate Report explained that "the freedom-of-travel principle is sufficiently important that it should be a matter of law and not dependent upon a particular Administration's policy." ${ }^{119}$ The Report also explained that Congress wanted to support the Helsinki agreement on human rights, which called for greater freedom of international travel. ${ }^{120}$

\footnotetext{
${ }^{114}$ Agee v. Vance, 483 F. Supp. at 732.

115 Agee, 101 S. Ct. at 2779.

11622 C.F.R. § 51.72 (1977), added by 31 FED. REG. 13544 (1966).

117 See text accompanying note 42 supra.

${ }^{118}$ Act of Oct. 7, 1978, § 707, 92 STAT. 992-993, amending 8 U.S.C. § 1185 . Under this statute, area restrictions may only be used in cases involving war, ongoing hostilities, or public health hazards.

119 S. Rep. No. 842, 95th Cong., 2d Sess. 14 (1978).

${ }^{120} \mathrm{Id}$. at 15 . On the Helsinki provisions relating to travel, see HuMAN RIGHTs, INTERNATIONAL LAW AND THE HeLSINKI ACCORD 172-80 (Buergenthal ed. 1977); Turack, $A$ Brief
} 
The Senate Report does contain one sentence that mildly supports the Agee holding. The sentence states that the President should be able to control travel which is "inconsistent with a greater government interest, such as preventing a citizen who is seeking to avoid the judicial processes of the United States." ${ }^{121}$ In the lower court, Judge MacKinnon argued that this was an endorsement of the Agee regulation. ${ }^{122}$ This argument, however, requires a series of implausible assumptions. First, the argument assumes that Congress remembered the Agee regulation. According to the Court, the regulation was last brought to the attention of Congress in $1966 .{ }^{123}$ After that date, it was invoked only once, in an obscure 1970 incident. ${ }^{124}$ It seems unlikely that by 1978 Congress recalled either the incident or the regulation itself. Second, assuming Congress did recall the regulation, the argument assumes that Congress approved of the regulation. The Agee regulation and the area-restriction regulation allowed travel control based on similar standards involving serious damage to U.S. policy. In view of this similarity, no reason exists to assume that Congress drew any fine distinction between the two regulations. Third, if Congress did intend to draw such a distinction, the argument assumes that the Senate committee simply neglected to mention the Agee regulation in its report, while using the less relevant example of persons evading judicial process. If Congress was aware of the Agee regulation, despite that regulation's obscurity, and if Congress did intend to distinguish that regulation from the area restriction regulation, despite their similarity, then Congress's silence on the subject is certainly baffling.

The amendment to the Travel Act is less ambiguous in its implications. The "state of emergency" declared in 1958 was about to expire, and with it the requirement of a passport for foreign travel. Representative Eilberg introduced a floor amendment to deal with this problem. His amendment, while retaining the requirement of a passport for foreign travel, actually represents a complete repudiation of the philosophy of the prior Travel Act.

Review of the Provisions in Recent Agreements Concerning Freedom of Movement Issues in the Modern World, II CASE W. Res. J. INT'L L. 95, 105-14 (1979).

121 S. Rep. No. 842, 95th Cong., 2d Sess. 14 (1978).

122 Agee v. Muskie, 629 F.2d at 108.

${ }^{123}$ See Agee, 101 S. Ct. at 2778.

${ }^{124}$ See text accompanying notes 74-93 supra. 
That statute was intended to control travel in time of war or national emergency. Eilberg's purpose was quite different, as he carefully explained: ${ }^{125}$

Although the continuation of the passport requirement for citizens may appear to impede travel, I believe the impediment will occur if the passport requirement is allowed to lapse. Passports permit travel with a minimum of inconvenience because most countries in the world now require travelers to be documented with passports which show both citizenship and identity. Abandoning the passport requirement for U.S. citizens and nationals may result in many cases where travelers arrive at their countries of destination only to discover that they are not allowed entry because they lack the proper documentation.

In my amendment, I am deleting the provisions in the administration's bill for an administrative penalty against persons who violate any provisions of section 215 . The thrust of my amendment is to facilitate travel, not to obstruct it and cover it with penal overtones.

Other representatives also commented on the need for a passport requirement to facilitate travel. ${ }^{126}$ As finally passed, the statute omitted any penalty for travel without a passport. ${ }^{127}$ The Agee opinion contains no hint of this legislative history.

The Agee Court purported to find implicit congressional approval for travel controls based on national security. Instead, the legislative record demonstrates almost complete hostility to travel control for over twenty-five years before Agee. The travel control program adopted in the early years of the Cold War consisted of three elements: area restrictions, a penalty for travel without a passport, and denial of passports to subversives. In 1958, Congress refused to reinstate the last element, and in 1978 it abolished the other two. The Agee regulation, on the other hand, derived from a minor, late addition to the travel control program. It had been applied rarely, under peculiar and obscure circumstances. It was never brought forcefully to the attention of Congress. To infer congressional approval under these circumstances seems to surpass the bounds of credibility.

125124 CONG. REC. H4689 (May 31, 1978) (daily ed.).

${ }^{126} \mathrm{Id}$. at $\mathrm{H} 4690$ (remarks of Rep. Zablocki); ibid. (remarks of Rep. Fish).

${ }^{127}$ Act of Oct. 7, 1978, § 124, 92 STAT. 971, amending 22 U.S.C. $\$ 21$ la. 
III.

Agee is an important case for several reasons. Its approach represents a major shift from previous travel cases such as Kent. Moreover, its holding will govern travel control for the future. Finally, its mishandling of the historical record raises disturbing prospects for future cases involving national security questions.

To begin with the question of analytic approach, Agee clearly represents a major shift in theory. Kent laid heavy stress on the importance of the right to travel and took a correspondingly grudging approach to discretionary travel controls. Agee, on the other hand, distinguishes the right to travel within the United States from the mere freedom to travel outside the United States. ${ }^{128}$ It takes a correspondingly generous view of executive discretion. For three reasons, the Kent approach is preferable, even ignoring the matter of stare decisis.

First is the importance of the right to travel itself. ${ }^{129}$ As the Kent Court said, "[f]reedom of movement is basic in our scheme of values." ${ }^{130}$ One important aspect of international travel is its relation to freedom of speech. Without the right to travel, criticism of foreign policy is greatly impeded. ${ }^{131}$ More generally, as Zechariah Chafee explained in a passage quoted by the Court in Kent: ${ }^{132}$

Foreign correspondents and lecturers on public affairs need first-hand information. Scientists and scholars gain greatly from consultations with colleagues in other countries. Students equip themselves for more fruitful careers in the United States by instruction in foreign universities. Then there are reasons close to the core of personal life-marriage, reuniting families, spending hours with old friends. Finally, travel abroad enables American citizens to understand that people like themselves live in Europe and helps them to be well-informed on public issues. An American who has crossed the ocean is not obliged to form his opinions about our foreign policy merely from what he is told

\footnotetext{
${ }^{128}$ Agee, $10 \mathrm{I} \mathrm{S}$. Ct. at 2782 . On the origins of constitutional protection for interstate travel, see NowaK, RotuNDA, AND Young, Constitutional LAW 668-74 (1978).

${ }^{129}$ As Judge Edgerton said a quarter of a century ago, "lron curtains have no place in a free world." Briehl v. Dulles, 248 F.2d 561, 596 (D.C. Cir. 1957) (dissenting opinion).

130 Kent v. Dulles, 357 U.S. at 126.

${ }^{131}$ Indeed, this is a major reason why so many nondemocratic countries restrict foreign travel. See Comment, note 1 supra, at 171, 202; Parker, note 1 supra, at 853, 853-54.

132 Chaffe, Three Human Rights in the Constitution of 1787, 195-96 (1956), quoted in Kent v. Dulles, 357 U.S. 116, 126-27 (1958).
} 
by officials of our government or by a few correspondents of American newspapers. Moreover, his views on domestic questions are enriched by seeing how foreigners are trying to solve similar problems. In many different ways direct contact with other countries contributes to sounder decisions at home.

The principle of free travel is embodied not only in judicial opinions but also in other guarantees of open borders, such as the statutory right of expatriation ${ }^{133}$ and the unchallenged right of any citizen to return to this country. ${ }^{134}$ The approach taken in Kent gave recognition to the importance of travel by requiring a clear delegation of authority to restrict travel.

The second reason for preferring Kent relates to the problem of executive discretion. Kent's grudging attitude toward executive discretion is amply supported by history. Several glaring examples from the Cold War period have already been considered; the Isacson episode is perhaps the worst. ${ }^{135}$ Numerous other instances support Jaffe's observation that "[w]hat began in an alarmed concern for the country's safety concludes in routines of unmitigated gall." ${ }^{136}$ This was true, not only in the Cold War when Jaffe wrote, but also in other periods. At various times, we have denied passports to writers whose work was not considered "constructive," 137 to Mormons seeking to travel abroad as missionaries, ${ }^{138}$ and to chess champions seeking to play on forbidden territory. ${ }^{139}$ The Agee Court seems to have assumed that the discretion to control travel had only been exercised on a principled basis. Too many counterexamples exist to allow reliance on this assumption.

The third reason for preferring Kent to Agee is that Kent aligns more closely with congressional intent. Since Kent, Congress has strongly supported the principle of freedom of travel. Despite urgent pleas from the President, Congress refused to supply the statutory power held lacking in Kent. Even supporters of the override legislation were unwilling to give the President as much dis-

${ }^{133}$ See Jaffe, note 2 supra, at 17, 18-19; Parker, note 1 supra, at 856 and n.12.

${ }^{134}$ Even Agee was offered permission to return home. See Agee, 101 S. Ct. at 2773 n.16. See also note 101 supra (government concession that citizens cannot be denied entry).

${ }^{135}$ See text accompanying notes 83-87 supra.

${ }^{136} \mathrm{Jaffe}$, note 2 supra, at 28.

${ }^{137}$ Comment, note 2 supra, at 178.

${ }^{138}$ Jaffe, note 2 supra, at 22-23.

${ }^{139}$ Travel and the First Amendment: Zemel v. Rusk, 13 U.C.L.A. L. REv. 470, 481 (1966). 
cretion as he requested. ${ }^{140}$ Twenty years later, Congress abolished the other major elements of the Cold War program of travel control. In essentially abolishing area controls, the Senate committee stressed the importance of the freedom-of-travel principle and its reluctance to leave the matter to Presidential discretion. It also expressed its firm support for the Helsinki agreement favoring looser restrictions on travel everywhere in the world. In the House, penalties for travel without a passport were abolished. The reason, as the sponsor of the measure explained, was that passport rules should be used to facilitate travel, not to hinder or penalize it. With this measure, the legal basis for travel control vanished. In sum, not only the holding but also the underlying policies of Kent have received congressional endorsement. This is of critical importance, because both Kent and Agee proceed from the premise that the President's power flows from Congress. Indeed, even if the President did have some inherent power in the area, that power would be greatly diminished by Congressional disapproval. ${ }^{141}$

The Agee opinion is thus a misguided retreat from the Kent analysis. Even more important, perhaps, is the change in judicial attitude between the two cases. Kent is part of a series of cases using nonconstitutional grounds to protect civil liberties. In Kent and similar cases, the Court required clear statutory authority, explicit and narrow guidelines, full procedural protection, and other safeguards before allowing the government to burden the exercise of important rights. ${ }^{142}$ The benefits of this approach are obvious. It avoids constitutional rulings and thus averts direct confrontations between the Court and other branches of government. At the same time, it gives the other branches an opportunity for sober reconsideration before they proceed. At times, such reconsideration has led to a change in

${ }^{140}$ See 105 CONG. ReC. 18445 (1959) (remarks of Rep. Selden); id. at 18448 (remarks of Rep. Morgan); ibid. (remarks of Rep. O'Hara); id. at 18613 (remarks of Rep. Fascell); 104 CoNG. Rec. 19655 (remarks of Rep. Selden) (1958); S. Rep. No. 1881, 86th Cong., 2nd Sess. 7 (1960). Opponents of the measure stressed the dangers of excessive executive discretion. See 105 CONG REC. 18612, 18618 (1959) (remarks of Rep. Porter); id. at 18616 (remarks of Rep. Hays); id. at 18623 (remarks of Rep. Fulton); id. at 18449-50 (remarks of Rep. Celler); 104 CONG REC. 13773-74 (1958) (remarks of Sen. Humphrey).

${ }^{141}$ See Youngstown Sheet \& Tube Co. v. Sawyer, 343 U.S. 579, 637-38 (1952) (Jackson, J. concurring), quoted with approval in Dames \& Moore v. Regan, 101 S. Ct. 2972, 2986 (1981).

${ }^{142}$ See, e.g., Watkins v. United States, 354 U.S. 178 (1957); Service v. Dulles, 354 U.S. 363 (1957); Noto v. United States, 367 U.S. 290 (1961); Yates v. United States, 354 U.S. 298 (1957). 
decision. After Kent, for example, Congress proved unwilling to authorize denial of passports to Communists. ${ }^{143}$ By requiring narrow, carefully drawn regulations, the Court also helped minimize the side effects of regulation on the exercise of First Amendment rights.

The Agee opinion has little in common with these cases. The Agee opinion contains alarming distortions of both the Court's prior decisions and the historical record. At a time when a city's billboard ban requires many pages of agonizing judicial appraisal, ${ }^{144}$ Agee's First Amendment claim is brushed aside in a few sentences. ${ }^{145}$ In short, the opinion seems anxious to uphold the President's national security prerogatives without serious scrutiny.

Agee is not the only recent case in which the Court has taken shortcuts in its haste to defend the nation's security. The more obvious example is Snepp v. United States. ${ }^{146}$ Snepp involved another former CIA agent who had violated his secrecy agreement with the government. The Fourth Circuit held the agreement valid, upheld an injunction against future violations, and remanded for a determination of damages. ${ }^{147}$ Snepp petitioned for certiorari. The government filed a conditional cross-petition, asking the Court to review another aspect of the remedy if it granted Snepp's petition. The Supreme Court summarily reversed the lower court on the remedy issue and imposed an extremely harsh remedy. Because Snepp had failed to allow the CIA to check his manuscript for classified material, the Court held that the CIA was entitled to all of Snepp's book profits, even though the book concededly did not contain classified information. First Amendment problems were brushed away in a footnote. ${ }^{148}$ Nor was the Court concerned about the complete absence of any statutory basis for this remedy. All this was done summarily, without the benefit of oral argument or full briefing.

143 See note 113 supra.

144 See Metromedia Inc. v. City of San Diego, $101 \mathrm{~S}$. Ct. 2882, 2885-2925 (1981), in which five Justices found it necessary to write separately and at length on this issue.

145 See Agee, $101 \mathrm{~S}$. Ct. at 2782-83. For a brief critique of the Court's First Amendment discussion, see Kamisar, The Agee Decision, NEw YoRk Times, July 28, 1981, at 21, col. 1.

146444 U.S. 507 (1980) (per curiam).

147 United States v. Snepp, 595 F.2d 926 (4th Cir. 1979).

148444 U.S. at 513 n. 8. 
Agee and Snepp raise disturbing prospects. Of course, the temptation is always greatest to cut a few corners when national security is at stake. Precisely for that reason, it is critical that the Court hold rigorously to its highest standards of craftsmanship in such cases, while demanding scrupulous attention to legality from the other branches of government.

IV.

Given Agee's conduct, the Court's willingness to limit his travel is not a complete surprise, especially if it thought its decision would affect only a few similar individuals. The regulation at issue in Agee required a finding of "serious" damage to national security or foreign policy. In its review of history, the Court found only three other instances in thirty years when this standard had been met. As we have seen, even these instances were distorted to maximize the appearance of a threat to national security. ${ }^{149}$ Thus, the Court may well have thought its decision would affect only individuals presenting truly extraordinary threats to national security. This belief may explain the Court's lack of concern for the civil-liberties implications of its decision, because the right to travel clearly does not encompass Agee's attempt to travel abroad to disclose classified information. ${ }^{150}$ It is not hard to understand the temptation to bend the law, just a little, in order to thwart Agee.

The Court paid a heavy price for yielding to this temptation. At considerable cost to intellectual integrity, the Court did violence both to its own precedents and to clearly manifested congressional intent. Moreover, history gives good grounds for questioming whether the narrow restrictions on travel upheld in Agee will long remain narrow in their application.

In exchange for this damage to the law, the Court seems to have gotten little in return. Before receiving the Court's endorsement, the Agee regnlation was rarely used, and then under questionable circumstances involving relatively insignificant threats to national

\footnotetext{
${ }^{119}$ See text accompanying notes 74-93 supra.

150 See Zemel v. Rusk, 381 U.S. 1, 26 (1965) (Douglas, J., dissenting) (right to travel is "at the periphery of the First Amendment"; peacetime restrictions on travel "should be so particularized that a First Amendment right is not precluded unless some clear countervailing national interest stands in the way of its assertion").
} 
security. ${ }^{151}$ Even with respect to Agee himself, the regulation seems to have been largely ineffective. Shortly after the Court's decision, Agee announced his determination to continue his campaign against the CIA and obtained a new passport from Grenada. ${ }^{152}$

The basic error in Agee was the Court's decision to bend the law to impose sanctions on a single individual. In this case, the individual involved may well have deserved some form of sanction, perhaps even the kind authorized by the Court. But in bending the law to reach this one individual, the Court has endangered the liberties of many more. Prior to Agee, freedom of travel was protected by the Kent decision and by several manifestation of congressional intent. After Agee, these barriers have been breached, leaving as safeguards only executive restraint in exercising discretion and judicial willingness to intervene on an ad hoc basis.

151 See text accompanying notes 74-93 supra.

152 Agee, note 6 supra, at 15, col. 1; Pbilip Agee's Grenadian Pasport, NewsweEk, August 10,1981 , at 15 . 